\title{
Sustainable Masjid Architecture and Public Buildings
}

\author{
Zainon Tohid *, Asiah Abd. Rahim \\ Kulliyah of Architecture and Environmental Design (KAED),50728 K.Lumpur, Malaysia
}

\begin{abstract}
A hydroelectric project proposed by Tenaga Nasional Berhad in Telom, Pahang, Malaysia will inundate six Orang Asli villagers whose residents have relocated to a new resettlement. However, TNB still needs their agreements and provide fair and agreeable compensation. This paper analyzes the process associated with the exercise. It is a descriptive analysis of activities conducted in preparing the plans as well as principles and values considered in calculating the proposed compensation and resettlement. It is hoped that the more sensitive and inclusive approach can be emulated in future projects affecting Orang Asli and others affected by developments

(C) 2016. The Authors. Published for AMER ABRA by e-International Publishing House, Ltd., UK. Peer-review under responsibility of AMER (Association of Malaysian Environment-Behaviour Researchers), ABRA (Association of Behavioural Researchers on Asians) and cE-Bs (Centre for Environment-Behaviour Studies, Faculty of Architecture, Planning \& Surveying, Universiti Teknologi MARA, Malaysia.
\end{abstract}

Keywords: Orang Asli; compensation plan; resettlement plan; Telom Hydroelectric Project

\section{Introduction}

The objective of this paper is to explore the approaches related to sustainable Masjid architecture and public buildings. Masjid is a place of great importance for Muslims for worship, therefore feeling comfortable and calm is crucial to seek a feeling of peace and serenity. Nowadays, the planning of masjids has transformed from the primary multi-functional main prayer halls into complexes. This change is in line with current needs and functions of the masjid not only for worship but as a community center. As one of the Islamic non-profit organizations, Masjids are required to conduct quality programs, according to Islamic principles with limited funds from state and federal government. This high expectation becomes stronger when it comes to large masjids that are trusted by the Muslim communities. Malaysia has launched the Green Building Mission in March 2007 to increase the awareness of sustainability in the construction industry including public and commercial buildings. Therefore, sustainable development has been improved including public buildings as well as religious buildings such as Masjid. The methodology used will be table research based on literature review. The analysis will be through observation and secondary data. In conclusion, further research will be done to identify rules and guidelines to assist players in building industry and other stakeholders to include green and sustainable into planning, design, construction and maintenance of built environment.

* Corresponding author. Tel.:

E-mail address: zainont@gmail.com

(C 2016. The Authors. Published for AMER ABRA by e-International Publishing House, Ltd., UK. Peer-review under responsibility of AMER (Association of Malaysian Environment-Behaviour Researchers), ABRA (Association of Behavioural Researchers on Asians) and cE-Bs (Centre for EnvironmentBehaviour Studies, Faculty of Architecture, Planning \& Surveying, Universiti Teknologi MARA, Malaysia.

DOI: http://dx.doi.org/10.21834/e-bpj.v1i1.200 


\section{Historical background - Sustainable development}

\subsection{General background on sustainable}

Malaysia Green Building Mission launched in 2007. The objective is to raise the level of awareness, promoting, and consolidating efforts in achieving sustainable building and construction in Malaysia (Esa et al., 2011). Due to that, sustainable development has been improving including sustainable commercial buildings as well as religious buildings including Masjid. Meanwhile, according to Malaysia Demographic Profile in 2014, it is stated that the population in Malaysia is 28.3 million, of which approximately $61.3 \%$ percent of 17.34 million people are Muslims. Therefore, Masjids are part of the ordinary scene in Malaysia because it is the most important building in Islam, and the number of new masjids builds every year are increasing.

Ministry of Green Technology and Water (KETTHA), Malaysia define green technology as the development and product application equipment and systems to conserve the environment and natural resources and minimize or reduce the negative impact of human activities. Criteria for green technology are to decrease the degradation of the environment, low greenhouse gas emission, improved environment for all forms of life, the use of natural resources while promoting the use of renewable resources.

Previous studies showed that Green architecture involves a combination of values, environmental, social and technological to reduce the negative environmental impact of buildings by increasing efficiency and moderation in the use of building materials, energy, and development space (Attman, 2010). Shafii added that in developing countries, sustainability agenda would focus on the relationship between construction and human development and the alleviation of poverty. He further highlighted that lack of resources to improve technologies may affect the environmental aspects. Like other development country, Malaysia needs to balance environmental conservation and economic development (Shafii \& Othman, 2007). Therefore, Malaysia has recognized the concept of sustainable development, and this was informed in the policies, vision, mission, and plans and is actively involved in international sustainable activities. Also, City Hall of Kuala Lumpur and Putrajaya have considered applying green building index in all physical development.

\subsection{Sustainable development}

\subsubsection{Sustainable construction}

The foundation of sustainable construction development is the green building. Through sustainable development concept, the building industry can contribute in a positive and proactive manner towards environmental protection (Abidin, 2010). Presently, the idea of the sustainable development covers three primary objective that is environmental protection, social well-being, and economic prosperity (Abidin, 2010). According to Nazirah, 2010, active promotion of sustainable development by the Malaysian government, non-organizations and education institutions in the past five years have shown some encouraging process in this field.

\subsubsection{Energy efficient and green building}

Green building initiatives in Malaysia has received bigger attentions from government agencies, private organizations and the public at large. National Green Technology Policy (NGTP) was launched in 2009. It focused on green buildings with the application of renewable energy (RE) and energy efficiency (EE), as well as the Green Building Index. One of most cost-effective measures for reducing carbon dioxide (CO2) emission is through improving energy efficiency in buildings. The approach is by using a process that is environmentally responsible and resource-efficient throughout a building's lifecycle: from the design phase, construction, operation, maintenance, renovation, and demolition works (Suhaida et al., 2013).

According to Malaysia Green Building Index,green building focuses on increasing the efficiency of resource use such as energy, water, and materials while reducing building impact on human health and the environment during building's lifecycle, through better siting, design, construction, operation, maintenance, and removal. Green Buildings should be designed and 
operated to reduce the overall impact of the built environment on the surrounding. Green buildings are designed to reduce adverse impacts on the environment while increasing the occupant health. Factors to be considered are sustainable site planning, safeguarding water and water efficiency, renewable energy, energy efficiency and lower greenhouse gas emissions, conservation and the reuse of materials and resources and improved health and indoor environmental quality (Samari et al., 2013).

Meier et al., 2002 concluded that three criteria for an energy efficiency buildings are the building must be equipped with efficient equipment and materials appropriate for the location and conditions; it must provide amenities and services appropriate to the building's intended use; and operated in such a manner as to have a low energy consumption compared to other, similar buildings. An efficient building must, at a minimum, be above average in all three aspects. He also concluded that the usage of solar technology as an energy efficient approach would result in a cleaner environment in the long term. In Malaysia, Sultan Ismail Mosque, Universiti Teknologi Malaysia (UTM) had been installed with a new grid-tied PV solar panel system and the findings show that it helps to reduce the university's electricity bill by RM33,000.00 annually with a reduction of $47 \%$ (Rashid et al., 2011).

\subsubsection{Thermal comfort}

According to S.H. Ibrahim et al. 2010, the mosque should be provided with an acceptable level ofthermal comfort to seek serenity and focus for worship. The thermal comfort conditions in Masjid Al-Muttaqin, Kota Samarahan, Sarawak shows that it was not achieved due to the overheated heat entering from the roof. The heat may be reduced by using good thermal insulation. Acceptable thermal comfort in mosque buildings is crucial for worshippers to be focused while praying. However, there is not much information available regarding thermal comfort conditions in Malaysian mosque. Furthermore, some new mosques have been built recently, however, design criteria for acoustical behavior and thermal comfort often being neglected (Idris, 2014).

\subsubsection{Operation and maintenance}

Woon et al., 2014 concluded in his research that successful green building is more than just green design and technology. Operation and maintenance should also be carried out in a green way. Therefore, he suggested that design for maintainability for operations and maintenance need to be included in the Green Building Index (GBI) rating tools for green building certification to ensure that Malaysian green buildings are entirely green in its life cycle.

\subsection{Masjid architecture}

\subsubsection{Community mosque}

Masjid architecture is a part of Islamic architecture. The word "masjid" is found throughout the Qur'an, most frequently with the reference to the sanctuary of Kaaba in the city of Mecca. The most important function of the masjid is a place of prayers while the next important feature is the centre for religious education and also a place for the development of the Muslim community (Mohamad Tajuddin, 2014) while another researcher (Rosniza Othman, 2007) mentioned, the idea of community mosque has evolved since the early era of Islamic development, and the 'Prophet Mosque' is the most prominent example of communal mosque in terms of functionality and usage.

\subsubsection{Architecture, building, engineering and maintenance of Masjid}

In Malaysia, Islamic place of worship can be categorized in six different hierarchies which are national masjid, state masjid, district masjid, village or town masjid, surau and prayer room (MS2577:2014, pp. 2-5). According to Malaysian Standard, Architecture and Asset Management of Masjid, Code of Practise, MS2577:2014, general design considerations of a masjid are qiblah direction, prayer hall, mimbar, mihrab, dome or minaret, ablution, and toilet. This document also covers on safety and security, schedule maintenance, green building element for energy efficiency and water efficiency which should comply with the requirements of MS 1525:2014 (2nd Revision). 


\subsubsection{User's accessibility and mobility}

Accessibility is essential to be provided for all Muslim to pray at Masjid comfortably regardless of ability or disability. Providing accessibility for all Muslims in ablution area and toilets is recommended regarding Malaysian Standards, MS 2015: 2006, Public Toilet and related international and local building Acts/By-Laws. Recommendation on good universal design practices to improve existing Masjid's facilities is the main aspect to be considered. The application of universal design practices should be at the earlier stage of developing a Masjid (Asiah Abdul Rahim et al., n.d.). Universal Design principles are equitable use, flexibility in use, simple and intuitive use, perceptible information, tolerance for error, low physical effort and size and space for approach and use. Four design components for a mosque are accessibility needs, a comprehensive circulation of users, praying time reminder and khutbah (sermon) display which accessible to all Muslims. Universal mosque design is how the mosque design familiar with the users (Harry Kurniawan, 2011).

\section{Research Methodology and Analysis Based on Previous Studies}

The method used will be table research. The first author is at the early stage of this research, therefore some secondary data will be used to see what are the issues related to sustainable masjid and public buildings, factors that influence user comfort after occupancy and how sustainability helps to reduce maintenance cost in the long term and factors affecting user perception towards green and sustainable building.

\subsection{Perception towards energy efficient building}

Ali and Zainordin, 2013 has conducted research on the effectiveness of green building, Zero Energy Office. The assessment using LEED assessment checklist including energy efficiency, water efficiency, conservation and natural resources, site design, durability, indoor air quality and Leadership in Energy and Environmental Design (LEED). However, it has limitations of findings and need to narrow the topic to a particular category and to have more participants involved to have better results.

Another results of research by Zainordin et al., 2012 concluded that the perception of an energy efficient building owned by the Ministry of Energy, Green Technology and Water (KETTHA) revealed that users have mixed feeling towards light and space, especially with the use of new working practices and these also influence the nature of their jobs as well as their position in the office. Nonetheless, energy efficient building does provide thermal comfort, healthy living, lower heating costs and an overall high degree of the user. Research on users' perception of energy efficiency in school design revealed that human behavior influences the entire energy consumption of the building. The findings show that there is a relationship between the user perceptions of energy efficiency. As efficient users who care about energy consumption and design of schools in Malaysia which may aid at planning, design and management stages as guidelines in efficiency design needs. (Najib et al., 2015)

\subsection{Key findings of user's perceptions of sustainable buildings}

According to Baird, 2014, factors that influence user perceptions of sustainable building are the operational of the building, temperature and air in both winter and summer, lighting, noise, personal control of heating, cooling, ventilation, lighting, noise and satisfaction of design, needs, comfort overall, productivity, and health. He also concluded that people can provide one of the best measures of building performance since the experts are the user who knows most about using it. Therefore, it is important to add the view of users in the rating tools of existing sustainable building.

\subsection{Improving evaluation of energy efficient buildings}

Energy efficiency and user satisfaction in sustainable building is very complex because some buildings function very well and have a positive impact on well-being and performance, others do not. Some buildings have operational systems that are difficult to understand, or the users have not received sufficient information on how to operate them (Hauge et al., 2011). Hauge et al., 2011 suggested three ways to improve the evaluation of energy efficient building that covers the social contact of the users, the 
meaning of architecture and aesthetic and training. Future evaluations should focus on operation and maintenance over time such as user-friendly operating systems in energy efficient buildings.

\subsection{Factors affect the perception of green building}

Mansour and Radford, 2014 concluded that there are four major factors affect the perception of green buildings. The factors are the degree of belief in sustainability, the level of green certification, the congruity of design with the existing schema of similar conventional buildings and users' personal experience in the building. This factors may motivate occupant satisfaction with a green space. However, he suggests future research is still required to understand qualitatively and quantitatively how this will influence users' ongoing interactions with green space and the desire for more green building design.

\subsection{Post- Occupancy evaluation of energy-efficient buildings}

To improve the current conditions and guide the design of future buildings is by applying post-occupancy evaluation (POE) as a platform to conduct a systematic study of buildings once occupied. (Meir et al., 2009). In a research done by $\mathrm{Ng}$ and Akasah, 2013 mentioned that post-occupancy evaluation identify the problems related to energy-efficiency building that affect human comfort. In his research, he suggested that there is a significant gap between sustainable building rating tools and actual building performance post building occupancy. Additional features such as window blinds and other fans were installed in the building when the building is being used. Even though, it is a certified energy efficiency building, the research indicating small satisfaction towards building's thermal comfort and lighting condition. It shows that the maintenance plays an important factor in maintaining the energy-efficient building's performance. The designer was overly focused on maximizing daylighting features and neglected the issue of glare that may occur due to large window area. This might be due to the fact that the designer was overly focused on maximizing daylighting feature of the building and neglected the glare problems that may occur due to large window area (Ng \& Akasah, 2013).

Another research by Hazreena et al., 2015 on the post-occupancy evaluation of bioclimatic design building revealed that the daylighting and natural ventilation approaches at a residential college building have a significant impact on the perception and satisfaction level of the residents in a positive manner. Comfort levels according to the performance criteria: architectural elements, thermal comfort and indoor air quality, visual comfort, acoustic comfort and landscape features are achieved by the majority of the residents. Natasha and Husnul Nizam, 2009 suggested that Post-Occupancy Evaluation (POE) should be implemented as a real practice in Malaysia as benchmarking towards a sustainable environment.

\section{Conclusion}

In conclusion, this paper will give an overview of various research findings including the perception towards energy efficiency building. It will cover the key findings of user's perceptions, factors in improving the evaluation technique, factors that may affect the perception of green building, user's accessibility and mobility of Muslim in the masjid and how effective Post-Occupancy Evaluation (POE) method in reducing the disruption in building performance, especially for sustainable building. It is recommended further research will be done to identify rules and green guidelines to assist players in building industry including Local Authorities and other stakeholders to include green and sustainable into the design, construction and maintenance of built environment.

\section{References}

Amirul Imran, M. A., \& Nadzirah, Z. (2013). User Perception towards Green Building Practise at Pusat Tenaga Malaysia ( Geo Building ). In 2nd International Conference on Environment, Agriculture and Food Sciences.

Asiah Abdul Rahim, N. A. A. S. (2014). Universal Design From Islamic Perspective: Malaysian Masjid. Journal of Architecture, Planning and Construction Management. 
Asiah Abdul Rahim, Nur Amirah Abd.Samad, Che Raiskandar Che Rahim, A. B. (n.d.). Providing Accessibility for Persons with Disabilities ( PwDs ) in Malaysian Existing Mosques.

Asiah Abdul Rahim,Nur Amirah Abd.Samad, C. R. I. C. R. and A. B. (n.d.). Providing Accessibility for Persons with Dissabilities (PwDs) in Malaysian Existing Mosques.

Attmann, O. (2010). Green Architecture. The McGraw Hill Companies.

Baharudin, N. 'Athiqah, \& Ismail, A. S. (2014). Communal Mosques: Design Functionality towards the Development of Sustainability for Community. Procedia Social and Behavioral Sciences, 153, 106-120. http://doi.org/10.1016/j.sbspro.2014.10.046.

Baird, G. (2014). Users' Perceptions of Sustainable Buildings - Key Findings of Recent Studies. Renewable Energy, 73, $1-7$. http://doi.org/10.1016/j.renene.2014.04.004.

Ban Huat, N., \& Zainal Abidin Akasah. (2013). Post Occupancy Evaluation of Energy-Efficient Buildings in Tropical Climates-Malaysia. International Journal of Architectural Research, 7(2), 8-21.

Engg, M. (2010). Assessment of thermal comfort in the mosque in Sarawak, Malaysia. International Journal of Energy and Environment, 1(5), 861-870.

Harry Kurniawan. (2011). Familiarity in Designing a Mosque: A Practice of Universal Design. In UIA 2011 World Congress.

Hauge, Å. L., Thomsen, J., \& Berker, T. (2011). User evaluations of energy efficient buildings: Literature review and further research. Advances in Building Energy Research, 5(1), 109-127. http://doi.org/10.1080/17512549.2011.582350.

Hazreena Hussein, \& Adi Ainurzaman Jamaludin. (2015). POE of Bioclimatic Design Building towards Promoting Sustainable Living. Procedia - Social and Behavioral Sciences, 168, 280-288. http://doi.org/10.1016/j.sbspro.2014.10.233.

Hazreena, H., \& Adi Ainurzaman, J. (2015). POE of Bioclimatic Design Building towards Promoting Sustainable Living. Procedia - Social and Behavioral Sciences, 168, 280-288. http://doi.org/10.1016/j.sbspro.2014.10.233.

Huat, N., \& Akasah, Z. Bin. (2006). Post Occupancy Evaluation: A Newly Designed Building Performance Survey Framework for Energy-Efficient Building. In Management in Construction Research Association Postgraduate Conference. Retrieved from http://www.academia.edu/download/30832629/Post_Occupancy_Evaluation_A_Newly_Designed_Building_Performance_Survey_Framework_for_EnergyEfficient Building.pdf.

Idris Shamsuddin. (2014). Acoustic Quality and Thermal Comfort Inside AL-Bukhary Mosque, Senai, Johor Darul Takzim

Mansour, O. E., \& Radford, S. K. (2014). Green Building Perception Matrix , A Theoretical Framework. In 16th Annual Architectural Research Symposium, Finland (pp. 40-52).

Meir, I. A., Garb, Y., Jiao, D., \& Cicelsky, A. (2009). Post-Occupancy Evaluation: An Inevitable Step Toward Sustainability. Advances in Building Energy Research, 3(1), 189-219. http://doi.org/10.3763/aber.2009.0307.

Mohamad, I. S., Zainol, N. N., Abdullah, S., Woon, N. B., \& Ramli, N. A. (2014). Critical Factors That Lead to Green Building Operations and Maintenance Problems in Malaysia. Journal of Theoretical and Empirical Researches in Urban Management, 9(2), 68-86.

Mohd Najib Mohd Salleh, Mohd Zin Kandar, Siti Rasidah Md. Sakip, \& Noraini Johari. (2015). Users 'Perception of Energy Efficiency in School Design. Procedia - Social and Behavioral Sciences, 170, 155-164. http://doi.org/10.1016/j.sbspro.2015.01.025.

Mohd Reza Esa, Mohd Arif Marhani, Rostam Yaman, Ahmad Arzlee Hassan, Noor Hanisah binti Noor Rashid, \& Hamimah bt Adnan. (2011). Obstacles in Implementing Green Building Projects in Malaysia. Australian Journal of Basic and Applied Sciences, 5(12), 1806-1812. Retrieved from http://www.insipub.com/ajbas/2011/December-2011/1806-1812.pdf.

Mohd Reza, E., Mohd Arif, M., Rostam, Y., Ahmad Arzlee, H., Noor Hanisah, N. R., \& Hamimah, A. (2011). Obstacles in Implementing Green Building Projects in Malaysia. Australian Journal of Basic and Applied Sciences, 5(12), 1806-1812. Retrieved from http://www.insipub.com/ajbas/2011/December-2011/18061812.pdf.

Natasha Khalil, \& Husrul Nizam Husin. (2009). Post Occupancy Evaluation towards Indoor Environment Improvement in Malaysia 's Office Buildings. Journal of Sustainable Development, 2(1), 186-191.

Nazirah Zainul Abidin. (2010). Sustainable Construction in Malaysia - Developers 'Awareness. Proceedings of World Academy of Science, Engineering and Technology, 5(2), 122-129.

Ng, B.-H., \& Zainal Abidin, A. (2011). An Overview of Malaysia Green Technology Corporation Office Building: A Showcase Energy-Efficient Building Project in Malaysia. Journal of Sustainable Development, 4(5). http://doi.org/10.5539/jsd.v4n5p212.

Prof, A., Tajuddin, M., \& Rasdi, M. (n.d.). Mosque Architecture in Malaysia : Classification of Styles and Possible Influence. Journal Alam Bina, 1-37.

Samari, M., Godrati, N., Esmaeilifar, R., Olfat, P., \& Shafiei, M. W. M. (2013). The investigation of the barriers in developing green building in Malaysia. Modern Applied Science, 7(2), 1-10. http://doi.org/10.5539/mas.v7n2p1.

Suhaida, M. S., Tan, K. L., \& Leong, Y. P. (2013). Green buildings in Malaysia towards greener environment: challenges for policy makers. IOP Conference Series: Earth and Environmental Science, 16, 012121. http://doi.org/10.1088/1755-1315/16/1/012121.

Zainordin, N., Abdullah, S. M., \& Ahmad, Z. (2012). Light and Space: Users Perception towards Energy Efficient Buildings. Procedia - Social and Behavioral Sciences, 36(June 2011), 51-60. http://doi.org/10.1016/j.sbspro.2012.03.006. 